\title{
Нашият опит с Vestibo при пациенти с шум в ушите, намален слух и световъртеж
}

\author{
Д. Марев, Е. Ценев \\ Клиника по оториноларингология при УМБАЛ "Св. Марина" - Варна \\ Клиника по оториноларингология и пластична хирургия - Кьолн, Германия
}

\begin{abstract}
:
More than $50 \%$ of the patients seeking ENT-consultations throughout Europe complain of tinnitus, often accompanied by hearing impairment and/or vertigo.

This leads to important changes in their normal lifestyle. Seldom they could develop severe depression. In our daily practice we use Vestibo in patients, which complain of tinnitus, or hearing impairment. In such cases (especially in those with tinnitus) we do not have any objective tests to monitor the condition. Patients with tinnitus with objective cause are very rare. The majority of the patients complain of hearing a stable single tone and a smaller portion hear multiple tones. High tones are heard more often, than low tones. The clinical signs/complains are most pronounced in the cases with stable single tone, which appears to be louder during the night. Compared with the tinnitus the other clinical signs - the hearing impairment and vertigo are detectable with modern medical devices. Vertigo is actually a complex sign, rather than a separate clinical entity. We often use Vestibo in patients with tinnitus combined with ozone therapy or hyperbar oxygen therapy.
\end{abstract}

\section{Резюме:}

Повече от $50 \%$ от пациентите, посещавали ОРЛ-кабинети в Европа, се оплакват от шум в ушите, много често придружен от намален слух и/или световъртеж.

При тези пациенти се наблюдава в голяма степен нарушение в нормалния начин на живот и неговото качество. В редки случаи те изпадат в дълбоки депресивни състояния. В нашата ежедневна практика използването на медикамента Vestibo се налага при пациенти, които се оплакват от шум в ушите или намален слух. При тези оплаквания, особено при шум в ушите, ние не можем да обективизираме изследването. Много рядко се срещат пациенти с обективен шум в ушите. По-голям е броят на болните, които се оплакват от тон с прост характер, отколкото от множествени тонове, както и с по-висока тоналност, отколкото с ниска. Най-тежка е клиничната картина при пациенти с постоянен шум, който се засилва през нощта. За разлика от шума, намалението на слуха и световъртежът могат да бъдат добре обективизирани чрез модерна апаратура. Световъртежът е симптомокомплекс, а не отделна клинична единица. Много често прилагаме Vestibo при пациенти с шум в ушите, лекувани с озонотерапия или барокамера.
$\Pi$ овече от пациентите, посещавали ОРЛ-кабинети в Европа, се оплакват от шум в ушите, много често придружен от намален слух и световъртеж. В нашата ежедневна практика използването на медикамента Vestibo се налага при пациенти, които се оплакват от шум в ушите или намален слух или световъртеж.

Възрастовата граница, за съжаление, в последните години рязко се снижава и ние наблюдаваме хора на възраст под 20 години.

От разказа на болните и провеждането на функционалните изследвания ние установяваме моментното състояние на пациента и взимаме решение за неговото хоспитализиране или провеждане на лечение при домашни условия.

Много често, преди пациентът да попадне при специалист УНГ, той е бил лекуван от колеги ОПЛ или невролози (1). В повечето случаи се касае за различни заболявания, но като цяло генезът на световъртежа, шумът в ушите и увреденият слух е общ. След като сме провели стандартните изследвания, предприемаме лечение на болния (2). Разстройство на субективната концепция за ориентация в пространството, изразяващо се в илюзорно възприятие за движение на околното пространство или на субекта в пространството, често съпровождано от:

* неприятни вегетативни усещания (гадене и повръщане) (3);

* соматомоторни (нистагъм);

* координационни (атаксия);

* сензорни (тинитус, осцилопсия);

* психически (фобии) (4). 
Ние си поставихме следните задачи:

1. Дали болният за първи път получава тази симптоматика или за пореден път?

2. Колко е задълбочена симптоматиката?

3. За периферен или централен отоневрологичен синдром се касае и какво лечение е провеждано досега?

\section{Класификация на вертижните състояния по топичен принцип:}

1. Физиологични форми на световъртеж

* Кинетози

* Височинен световъртеж

2. Патологични форми на световъртеж

* Периферни (лабиринтни) - засягане на лабиринта

Ц Централни (неврогенни) -засягане на мозъчните вестибуларни ядра, проводящи пътища и интегративни центрове
Комбинирани - едновременно засягане на периферни и централни вестибуларни структури $(5,6)$

\section{Периферни вестибуларни синдроми}

1. Мениерова болест

2. Бенигнен пгароксизмален позиционен световъртеж

3. Възпалителни заболявания на лабиринта

4. Автоимунни лабиринтопатии

5. Вестибуларен неврит

6. Перилимфатична фистула

7. Травматични лабиринтопатии

8. Ото-баро-травматизъм

9. Лабиринтни Drop-атаки

10. Бенигнен пароксизмален световъртеж в детската възраст

11. Фамилен периодичен световъртеж и атаксия

12. Невроваскуларен компресивен синдром $(7,8)$.

\section{Клинични прояви на вертижните разстройства}

\begin{tabular}{|l|l|l|}
\hline \multicolumn{1}{|c|}{$\begin{array}{c}\text { Вид на клиничната } \\
\text { манифестация }\end{array}$} & \multicolumn{1}{|c|}{ Симптом/белег } & \multicolumn{1}{c|}{ Основен рефлекс } \\
\hline Окуломоторна & Нистагъм & Вестибуло-окуларен рефллекс \\
\hline Вестибулоспинална & Атаксия & Вестибуло-спинален рефллекс \\
\hline Вестибуловегетативна & Гадене, повръщане & Вестибуло-вегетативен рефрлекс \\
\hline Перцептуална & Световъртеж & Вестибуло-кортикален рефлекс \\
\hline
\end{tabular}

\section{Вертижни разстройства}

Най-често срещани (в 70\% от случаите) клинични състояния и заболявания, причиняващи вертижни разстройства:

1. Бенигнен пароксизмален позиционен световъртеж

2. Вестибуларен неврит

3. Психогенен (фобиен) световъртеж

4. Мениерова болест (9)

Вертижните разстройства протичат под форма на:

1. Атаки (пароксизмални форми на световъртеж)

2. Продължителни клинични състояния (перманентни форми на световъртеж)

\section{Вертижни разстройства - клинични форми}

1. Атаки от връщателен световъртеж * периферна топика - Мениерова болест, БППС-синдром, отосклероза и др. централна топика - вертебро-базиларна недостатъчност, базиларна мигрена и др.

2. Постоянен връщателен световъртеж

3. Позиционен световъртеж

4. Замаяност с разстройства на равновесието

\section{Мениерова болест}

Периферен вертижен синдром (лабиринтопатия) Вестибуло-кохлеарен синдром, с предимна топика на патологичния процес в лабиринта и в ретролабиринтното пространство $(10,11)$. Пристъпно заболяване с хронично протичане. Проявява се с атаки от:

1. световъртеж

2. засилващ се тинитус

3. прогресивно намаление на слуха от звукоприемен тип (обикновено се засяга едното ухо, в $20-40 \%$ от случаите засяга двете уши)

Продължителност на острите симптоми - 30 мин. до 24 часа. 
Тинитусът и невросензорната загуба на слухочувствителност стават трайни.

Към класическата атака от симптоми може да се прибави още:

1. чувство за натиск в областта на ухото

2. поява на хоризонтално-ротаторен нистагъм

3. тенденция за залитане

4. вегетативни прояви (бледост, изпотяване, гадене, повръщане) (12)

\section{Вариации}

1. Кохлеарен мениер (флуктуираща загуба на слуха, тинитус и натиск в областта на ухото, без световъртеж и повръщане).

2. Вестибуларен мениер (епизодични атаки от световъртеж без слухови нарушения, тинитусът не е задължителен) (13).

\section{Терапевтично поведение при болни с вертижни разстройства}

1. Медикаментозно

2. Физикално

3. Психотерапевтично

4. Оперативно

\section{Резултати и обсьждане}

Vestibo е препарат на първи избор, който може да повлияе както световъртежа, така шума в ушите и намалението на слуха, особено ако процесът е остър. Той действа едновременно на периферно и централно ниво, намалява тежестта и продължителността на пристъпите. Ние установихме, че няма странични реакции и има благоприятен ефект върху физиологичната дейност на вестибуларния и слуховия анализатор (14).
Много често прилагаме Vestibo при пациенти с шум в ушите, лекувани с лазер или барокамера. Забелязахме много бързо подобряване на болните. Шумът в повечето случаи се потиска бързо и за дълго време. Подобрява се също и слухът след едномесечна терапия с Vestibo 24 mg (15). Подобрението е в рамките на 10-15 db.За да понижим честотата и продължителността на пристъпите при болни с шум в ушите и световъртеж, в нашата клиника прилагаме Vestibo 24 mg между 4 и 6 месеца (16).

При пациенти с установен неврит на слуховия нерв правим профилактика два пъти годишно в продължение на два месеца, ако те нямат противопоказания от язвена болест. При тях наблюдаваме задържане на средната слухова загуба за период от 4-5 години (17). При редовното използване на Vestibo $24 \mathrm{mg}$ в $90 \%$ от случаите се стабилизира равновесието. При шум в ушите, ако той е установен, пациентите отчитат благоприятен ефект от лечението c Vestibo в 95\% от случаите.

При хрониците процентът се движи между 75 и $85 \%$ (18).

Решаващо за лечението е ранното започване на прием на Vestibo. Не на последно място трябва да отчетем, че Vestibo е изключително икономически изгоден медикамент, повлияващ симптомите както при остри, така и при хронични форми на световъртеж, намаление на слуха и шум в ушите (20).

Медикаментозното лечение е диференциално:

1. Лечение на острите вертижни атаки.

2. Лечение и профилактика в междупристъпния период.

\section{Антивертижни медикаменти}

\begin{tabular}{|c|c|}
\hline $\begin{array}{l}\text { Фармакологична група, } \\
\text { генерично наименование }\end{array}$ & Индикации \\
\hline \multicolumn{2}{|l|}{ Antihistaminica } \\
\hline Dimenhydrinat & $\begin{array}{l}\text { Мениерова болест, световъртеж при атеросклероза, постоперативно повръщане. } \\
\text { Профилактика и лечение на кинетозите, гадене, повръщане. }\end{array}$ \\
\hline Flunarizine & Вестибуларен световъртеж, мигрена \\
\hline Cinnarizine & Периферни и централни циркулаторни смущения, дразнене на вътрешното ухо \\
\hline Betahistine & Вестибуларни смущения, Мениерова болест \\
\hline \multicolumn{2}{|l|}{ Anticholinergica } \\
\hline Scopolamin & Болест на Паркинсон, профилактика на кинетози, морска болест \\
\hline
\end{tabular}




\begin{tabular}{|l|l|}
\hline Antidopaminergica & \multicolumn{2}{|l|}{} \\
\hline Dehydrobenzperidol & Световъртеж с централна или периферна генеза, повръщане \\
\hline Комбинирани препарати \\
\hline Dimenhydrinat/Cinnarizine & Световъртеж с различна генеза \\
\hline Vertigoheel & Вертижни състояния \\
\hline Други & Паметови смущения, периферни артериални разстройства, слухови смущения \\
\hline Gingko biloba extr. &
\end{tabular}

Лечението на световъртежа изисква комплексно поведение - невромодулиращо и съдоразширяващо.

\section{Невромодулиращ ефект на betahistine}

- Нормализира предаването на нервните импулси в централните и вестибуларни проводни пътища (19)

* Модулира процесите на възбуждане във вестибуларните ядра в мозъка

\section{1. Съдоразширяващ ефект на betahistine}

Подобрява мозъчната циркулация - разширява кръвоносните съдове в мозъка и вътрешното yxo

\section{Vestibo - показания}

1. За лечение на Мениерова болест, която се проявява със:

* световъртеж/вертиго (с гадене и/или повръщане)

* загуба на слуха (затруднено чуване)

* тинитус (шум в ушите)

* нарушено равновесие

2. Симптоматично лечение на вестибуларно вертиго

Vestibo - дозировка и дозови форми:

* Vestibo tabl. $8 \mathrm{mg}$ x 60

* Vestibo tabl. $16 \mathrm{mg}$ x 60

- Vestibo tabl. $24 \mathrm{mg}$ x 60

Високите дози показват по-продължителен ефект. Клиничната проява на тези ефекти са намалената честота и интензивност на световъртежа, снижаване на шума в ушите, подобряване на слуха в случаите на неговото понижаване.

\section{Възрастни}

* Дневна доза 24 - 48 mg, разделена в два или три приема

- Таблетките се приемат по време на хранене
Дозировката се определя според стадия на заболяването

* Подобрението при някои пациенти може да настъпи след 14-дневно лечение

* Курсът на лечение може да продължи от 1 до 3 месеца

\section{Деца}

* Ефективността и безопасността на продукта при деца и подрастващи до 18-годишна възраст не са установени

Vestibo - противопоказания и специални предупреждения за употреба

- Свръхчувствителност към активното или някое от помощните вещества на продукта

* Прилага се с повишено внимание при:

- пациенти с язвена болест, поради риск от възникване на диспепсия по време на лечението

- пациенти с бронхиална астма, уртикария, обриви и алергичен ринит

- пациенти, приемащи антихистаминови продукти

- пациенти с феохромоцитом

\section{Vestibo - лекарствени взаимодействия}

* Не се прилага едновременно с антихистаминови лекарствени продукти

* Етанол и салбутамол потенцират ефекта на Betahistine

\section{Vestibo - нежелани лекарствени реакции}

* Централна нервна система: сънливост, отпадналост, главоболие

* Кожа: обриви, пруритус

- Храносмилателна система: лек стомашен дискомфорт, които могат да се избегнат при приема на продукта с храна. 


\section{Заключение}

\section{Vestibo}

Намалява броя, остротата и продължителността на атаките от световъртеж, шум в ушите, прогресивна загуба на слуха. Премахва невровегетативните симптоми (гадене, атаксия, нарушено равновесие).

\section{Литература:}

1. Amelin AV, Skoromets AA, Gonchar MA, Tumelevich BCh, Nikitin KA Article in Russian Zh Nevrol Psikhiatr Im S S Korsakova. 2003; 103(5): 43-8

2. Betts et al. The effects of two anti-vertigo drugs (betahistine and prochlorperazine) on driving skills. Br J. clin Pharmacol 1991; 32: 45558

3. Betts et al. Effects of two antihistamine drugs on actual driving performance in O'Hanlon J, DeGier J (Eds) Drugs and Driving, Taylor and Francis, London Phila. 1984, 83-100

4. de Waele C, Muhlethaler M, Vidal PP. Neurochemistry of the central vestibular pathways. Brain Res Reviews 20 (1995) 24-46

5. Fischer AJEM. Histamine in the treatment of vertigo. Acta Otolaryngol 1991, 479, 24-28

6. Fujino $\mathrm{A}$ and others. Vestibular training for benign paroxysmal positional vertigo. Arch Otolaryngol HNS 1994: 120: 497-504.

7. Frew, I. J. and G. N. Menon (1976). "Betahistine hydrochloride in Meniere's disease." Postgrad Med J 52(610): 501-3.

8. Hampton T. Antipsychotic's link to weight gain found. JAMA 297; 12; 1305-1306 (2007)

9. James, A. L. and M. J. Burton (2001). "Betahistine for Meniere's disease or syndrome (Cochrane Review)." Cochrane Database Syst Rev 1: CD001873.

10. Lacour M, Sterkers $\mathrm{O}$. Histamine and Betahistine in the treatment of Vertigo. Elucidation of Mechanisms of action. Review Article. CNS Drugs 2001: 15(11) 855-870

11. Lacour M. Histamine vestibular function and vestibular compensation. Elsevier (Amsterdam) 1998. This monograph was supported by an educational grant from Solvay Pharmaceuticals.

\section{Vestibo}

Притежава невромодулиращ и съдоразширяващ ефект, с което отговаря на нуждата за комплексен подход при лечението на световъртеж от различен произход и Мениерова болест.
12. Meyer, E. D. (1985). "[Treatment of Meniere disease with betahistine dimesilate (Aequamen)--double-blind study versus placebo (crossover)]." Laryngol Rhinol Otol (Stuttg) 64(5): 269-72. Oosterveld, W. J. (1987). "Effect of betahistine dihydrochloride on induced vestibular nystagmus: a double blind study." Clin Otolaryngol 12(2): 131-5.

13. Mira E, Guidetti G, Ghilardi L, Fattori B, Malannino N, Maiolino L, Mora R, Ottoboni S, Pagnini P, Leprini M, Pallestrini E, Passali D, Nuti D, Russolo M, Tirelli G, Simoncelli C, Brizi S, Vicini C, Frasconi P.Eur Arch Otorhinolaryngol. $2003 \mathrm{Feb}$; 260(2): 73-7.

14. Rascol O, Hain TC, Benazet M, Clanet M, Montastruc JL. Antivertigo Medications and Drug-Induced Vertigo Drugs 50 (5) 777-791, 1995.

15. Sampson WI. Homeopathic vs. Conventional treatment of vertigo. Arch Otol HNS 129, 2003, p497

16. Smith WK, Sankar V, Pfleiderer AG.A national survey amongst UK otolaryngologists regarding the treatment of Meniere's disease. Laryngol Otol. 2005 Feb; 119(2): 102-5

17. Timmerman H. Histamine agonists and antagonists. Acta Otolaryngol (Stockh) 1991: 479: 5-11

18. Torok N. Old and new in Meniere's disease. Laryngoscope 1977, 85 , $131-135$

19. Wilmot, T. J. and G. N. Menon (1976). "Betahistine in Meniere's disease." J Laryngol Otol 90(9): 833-40.

20. Марев, Д. Периферический отолитовый синдром и очаговая инфекция. "Folia Otorhinolaryngologiae", S. Petersburg, Russia, vol 9, No. 1-2, 55-57, 2003. 